\title{
Yudanegara Teachings: The Discourse of Obedience In The Javanese Manuscripts Serat Sruti Jarwa And Its Relevance In The Present
}

\author{
Bayun Marsiwi ${ }^{1}$, Susanto ${ }^{2}$, Supana ${ }^{3}$ \\ \{bayun.marsiwi@student.uns.ac.id\} \\ Postgraduate Program in Cultural Studies, Sebelas Maret University, Jl. Ir. Sutami 36A, Surakarta \\ 57126, Indonesia
}

\begin{abstract}
This study aims to determine the discourse formation process in Yudanegara teachings in the Serat Sruti Jarwa manuscript. This research is a descriptive qualitative study to determine the discourse developed by K.P.A Sontakusuma using Foucault's theory. The results showed that Yudanegara's teachings contained a discourse of knowledge to legitimize the king's power. This imposition of knowledge becomes an ideology that makes the people submit to the authorities. The values that can be obtained from Yudanegara's teachings are (1) good manners, (2) obedience to the leadership, (3) accepting fate, (4) patient, (5) resignation, (6) respect. This value can still be used today.
\end{abstract}

Keywords: manuscript, sruti jarwa, yudanegara, teaching, discourse

\section{Introduction}

A manuscript is a handwritten essay, either original or a copy containing text or a series of words, which contains a certain content when viewed from a physical or tangible perspective and is not meaningless handwriting. The manuscript contains ideas and various kinds of knowledge about the universe according to the perception of a particular society. it usually contains moral, philosophical, religious and other teachings of good values [1].

One of the ancient Javanese manuscripts that have good values is Sêrat Sruti Jarwa (Srutjar) written by Kangjeng Pangeran Arya Sontakusuma, a collection of the Karaton Surakarta Hadiningrat's Library. This manuscript is a literary book adapted from Serat Nitisruti by Pangeran Karanggayam (a pujangga from the Sultanate of Pajang) with a detailed explanation of the teachings in it. This literary book was made during the King Pakubuwono IX era in 18641868 AD in Surakarta Hadiningrat. In Serat Sruti jarwa, there are many teachings that discuss leadership and good behavior when facing the king in the kingdom [2].

The main teaching in the Serat Srutjar manuscript is the teachings of Yudanegara. This teaching was given to the aristocrats in the Karaton Surakarta so that they could respect the power of a king. In Javanese society, this teaching is known as the teaching of manners. A member of Javanese society who has no manners will be said to be "ora duwe yudanegara" (having no manners). The life of Javanese people who have class differences makes the attitude of respect from the lower class to the upper class there is a certain rule in behavior and language. In this case, the Yudanegara teaching plays a role in regulating the manners of the lower class when facing the king. This teaching suggestion, as the people we must respect the king as we 
face God. The mandate and duties given by the king must be carried out as well as possible and must not disappoint the king, because the king is the representative of God in the world who gives us the glory of life. The meanings of Yudanegara in the manuscript cult the position of a king by using mythology and values, to solidify a person who is loyal to his king.

According to the discourse concept of Michels Foucault, this case is a text which contains a discourse of knowledge that is discouraged for society by the authorities to construct cultural behaviour patterns in order to get positive feedback from the community through the support of legitimacy and hegemony of power [3]. Barker has agreed with Foucault's theory, that a good ruler must consciously use knowledge through language to form a "cultural formula" for gaining power. The cultural formula is developed into a discourse in society and automatically constructs differentiation, discipline and justification of behaviour. The legitimacy of the ruler cannot be controlled consciously by the community, because personally and intrapersonal it has been formed into a whole subject through a discourse [4].

It is interesting to know why the teachings of Yudanegara were used by K.P.A Sontakusuma as a discourse on the interests of the king's power. The concept of Yudanegara teachings discusses the behavior patterns of ancient aristocrats and people. It is very interesting, there is a conflict over power, so the level of people's obedience is emphasized on a teaching of ethical manners to eliminate conflicts.

So, it is worth knowing how the relationship between leaders and subordinates that took place at that time underlies the creation of the literary work of Serat Sruti Jarwa. This research aims to uncover and find out the discourse development process of obedience to the king's orders by K.P.A Sontakusuma through the teachings of Yudanegara in Serat Sruti Jarwa. This study prioritizes a conceptual discussion using the discourse theory of Yudanegara teaching in Javanese society. The analysis of the discourse will revolve around the history of the creation of literary works and their use by kings through cult, mythology, or values related to the history of Javanese civilization in the Mataram Surakarta Hadiningrat dynasty.

\section{Research Methods}

According to Foucault's theory, discourse is a tool for the interests of power, hegemony, domination of science and culture to influence the mindset of society and bind it in certain classes [5]. Fairclough argues that discourse is a form of representation when someone sees reality [6]. In this study, the teachings of Yudanegara were used by K.P.A Sontakusuma, a royal family, to form the subservience of priyayi and the people when receiving orders from the king. The discourse contained in Serat Sruti Jarwa forms an ideology, people who accept Yudanegara's teachings become hegemonic, obey, and carry out all the king's orders with pleasure. Cavallaro argues that ideology is a cultural tool that contains practices, discourses, beliefs, and rituals to form a dominant world view of members of society [7].

Ideology also provides a view of subjectivity as a social identity that is closely related to power and knowledge. The cultivation of ideology through Yudanegara teachings is intended to provide a public perspective on the king as God's representative, so that all matters relating to the king's orders will be carried out seriously without any rejection. This research is a qualitative descriptive with a hermeneutic approach. The data is sourced from the Serat Sruti Jarwa manuscript and analyzed to see the discourse developed by K.P.A Sontakusuma with Foucault's theory of discourse. The social context of the community which became the 
background for the making of Serat Sruti Jarwa was also conveyed so that we could clearly understand the circumstances behind the creation of a discourse.

\section{Results and Discussion}

\subsection{The Social-Cultural Background of Sruti Jarwa}

The Javanese manuscript Serat Sruti Jarwa is a canonical literary work originating from the Surakarta Hadiningrat Palace which was written around 1864 AD. In this literary work, there are many moral teachings and manners, the most dominant is Yudanegara teaching which is the teaching talk about how to behave at a royal meeting when facing a king [8]. Kangjeng Pangeran Aria Sontakusuma the author of this manuscript is a prince, son of Pakubuwana V. At that time he served as one of the main princes of the kingdom who took care of all the royal needs. The prince who is also a royal family has a high level of knowledge of Javanese culture and literature. The social background when the creation of the Serat Sruti Jarwa (Srutjar) manuscript was in the mid-19th century.

At that time King Pakubuwana IX in Surakarta had been on the throne for four years. The condition of the people of Surakarta in the post-war era after the end of the Diponegoro war and other rebellions that brought the kingdom into crisis. During this period the development of literary writing in the palace experienced a period of progress known as the renaissance period of Javanese literature. The development of the writing of literary works was pioneered by the poets of Keraton Surakarta including Yasadipura II, Sastradipura, Panembahan Buminata, Ranggasutrasna, and up to Ranggawarsita [9].

\subsection{Yudanegara: The Discourse of Obedience in Serat Sruti Jarwa}

Moral and ethical improvements aimed at aristocrats, royal officials, and their subordinates were continuously intensified in order to prevent resistance and rebellion. Refinement is taught massively through literature. This literary work also contained a discourse of social control so that the order of the kingdom would not be disturbed by a rebellion, and to ensure that the princes and subordinates could obey the king's order [10]. Yudanegara's teachings contained in the literary works of Serat Srutjar:

Têgêse "yudanêgara" iku pêranging ati kang prayoga wong ana nagara. Lire yuda, pêrang. Iku têmbung kawi. Lire nagara, yèn lagi têmbunging candra sastra lire na, padhang.

Yèn têmbung kawi lire gara, gêdhe. Dene kumpuling têmbung sakarone na utawa gara iku yèn disarèhake mèngkene, amadhangi desa kang gêdhe. Dene kang dadèkake padhang yèn ora kêkurangan adil kang bênêr. [2600 / explanation of the 53th song]

Translate:

The meaning of "yudanegara" is a war in the heart of someone who has goodness in the country. The meaning of "yuda" is war, it is the word kawi. The meaning of "nagara" as a literary lunar word, the meaning of "na" is light. And the kawi's word "gara" means big. If the two words are put together, the meaning is to illuminate the big village, what makes light is justice and truth. [2600 / explanation of the 53th song]

The social condition of the community in the mid-19th century in the Keraton Surakarta Hadiningrat area still accepted the social class system well. The aristocratic / priyayi class, which is a relative and royal family, holds everything related to the government system. As for the social class below it is the "abdi dalêm" class or royal servants who serve everything needed by the kingdom, they are not a noble class but are accepted as kings' relatives. The lowest social 
class is the common people, they take orders and follow all the rules ruled by the king. The king occupies the highest social status in royal society, if it is described as a pyramid, the king is at the top and in charge of the aristocrats, priyayi, retinue, servants, and the people [11].

Kangjeng Pangeran Aria Sontakusuma was included in the priyayi / aristocratic class, according to his social status as a family and royal officials, he had an obligation to form royal authority, especially the authority of a king. The king is described as having supernatural powers and dignity as God's representative and divider of fortune for the people. One of them is through the teachings of Yudanegara. Here's an excerpt:

Lan manèh êndi ta bedane ratu karo wong cilik, ananging ewa mêngkono sarèhning kamulyaning ratu kabiyanton ing bala kabèh, dadi wênang yèn nglumpukna donya sabab anaa kang dinggo maringi marang balane kabèh. Lan wis pancène ratu iku nampani bulu pêti têka ing amanca kang supaya cukupa dinggo nutugi pambêkan bêciki nêgarane sak bawahane kabèh lan kênaa dinggo mulut marang atining bala.

[2636 / explanation of the 71th song]

Translate:

The status of the king is different from the people. glory belongs to the king, assisted by all soldiers and authorized to collect property to provide sustenance to the people. And it has been stipulated that the king will receive tribute from outside areas in order to provide the welfare of the state and all of his subordinates, as well as to please the people. [2636/ explanation of the 71th song]

K.P.A Sontakusuma built a discourse of obedience, that the king is the most noble figure as a divider of fortunes to the people. Whoever is devoted and becomes his subordinate will get a fortune. This is an ideological cultivation by the ruling class in the community around the palace so that they will see the king as an extraordinary person. The society which is constructed by this discourse causes the people to become subdued. Moreover, this discourse is conveyed by a ruler whose subordinates accept what their master says. In addition, in Yudanegara's teachings, it is said that they also play all roles of law in the world:

Lan manèh ratu iku wêsi asate sing akèh wêrnane lan sing nglarani kabèh utawa ngadêgêna gêdhong kang gêdhe, piranti diisèni wong katrap dosa kang mrêtanggung saliya putra niyaka sêntana. Dene yèn wis têmên bênêr pangadilane sênajan putra sêntana sapangisor amasthi ora ana suwala, malah adile kawruhan misuwur saisining bumi kabèh yèn sarta nurut kukuming agama sarak Rasulullah, sabab tanah Jawa iki nurut sarengate tanah Arab. Tanah Arab nurut kadising Rasullullah, mangka kadising Rasulullah amung nuduhake panggawe bêcik. Mulane satiba-tibane donya akherat slamêt.

[2640 / explanation of the 73th song]

Translate:

In addition, the king as the ruler of the law had many punishments for hurting and had the power to build a large prison as a means of punishing sinners. And when it has been tried, even if the king's son or family is guilty, he must be prepared to be punished. This legal justice will be famous throughout the world when bringing the Prophet's religious law. Because the land of Java is according to the Shari'a of the Arab land, Arab land according to the Hadith of the Prophet, while the Hadith of the Prophet only shows good things.

Therefore, try to save the afterlife. [2640 / explanation of the 73th song]

The role of the king as a court in the world causes all problems and resources to be regulated by the king and the royal government. The royal hegemony becomes strong in making decisions 
without any disturbance because the people have planted their thoughts that all matters have been decided by God's representatives in the world. The people can only be complacent, surrender, and willingly follow whatever the king and government say. The thought construction makes the king the source of truth, as there is the legitimacy of Islamic teachings contained in the Yudanegara teachings above.

Foucault's concept of bio-power is a form of power that regulates human life at the level of the mass population, so it is given a teaching and education for each individual. In this case using literary works. It aims to regulate human life in general [12]. In Yudanegara teaching, someone who faces the king is taught to maintain good manners and behavior. But in this lesson an ideological cultivation was also carried out in which the king faced was a holy figure shining as the incarnation of God. As the quote below:

Empaning yudanagara iku awor pangandikaning ratu kang arum. Saking kèhe pangandika saengga panah tumêmpuh nanging kang kêtiban ora kêna binastu. pinarêng tiba mênyang putra santana, pinarêng mênyang nayaka lan sapa kang kêtiban pangandika ya iku wong kêna panah yudanagara. Sabab wêtuning pangandika pêngarahe luwih alus tur bênêr pêtitis. Dene yèn dicandra pangandika kang yudanagara mêngkene, bêcik landhêp padhanging grahita ratu pinangka makutha. Lan paraning sasmita amung katampan padhange ciptaning mantri pamungkas, dene kamadakaning ratu pinangka binggêl. [2613 / explanation of the 59th song

Translate:

The word of the king is a Yudanegara arrow that contains an outpouring of a holy heart directed at anyone. Whoever is hit by Yudanegara's arrow will accept it happily, because it is likened to the word of the king as a shining crown. The king's gesture fell subtly to the prime minister. [2613 / explanation of the 59th song]

This quote is one of the realities developed by K.P.A. Sontakusuma as the ideology of society to submit to the king. The will of the aristocracy so that their subordinates and the people can always submit to their power. This is like what Foucault said that in order to gain power must go through a series of complex strategies with maneuvers to impose the will on others. K.P.A Sontokusuma with his knowledge has a dominating power. This will bring up a circle of political power that makes people around being obedient.

The power that K.P.A Sontakusuma has in his teachings is a desire that makes him a ruler. In this literary work his position is slightly lower than that of the king, but the people's respect for the royal family strengthens his power. This social reality cannot even be seen by the people who have been hegemony by the teachings and orders of the nobility. The next quote from Yudanegara's teachings is as follows:

Dene klakuane wong seba iku mung kudu nurut nyang ngarsane sing diseba. Yèn wis duwe pikir sing mêngkono ya iku sing dadi jalaran ngêmori kêrsaning gusti. Sabab wong ngawula iku rak kaya wayang, padha dikonclathu mêngkene mêngkono ya tirokna bae, wong dudu karêpmu dhewe.

[2583 / explanation of the 42th song]

Translate :

the behavior of someone who wants to serve must obey the king. When you already have such thoughts, it is a strong reason to be close to the king's wishes, because a citizen is like a puppet which can only imitate, because it is not our desire. [2583 / explanation of the 42th song]

From the quotation above, as people who face the king, they must comply with whatever the king wishes. This has entered into the discursive realm because there is a relationship 
between language, thought and knowledge that the rulers want to do by the hegemonic people. According to Ricour, discourse has four characteristics that accompany it, namely related to the time of a certain atmosphere, who is speaking, what is being discussed, and the world that is described.

The construction of Yudanegara teachings conveyed by K.P.A Sontakusuma to his subordinates will not be questioned anymore because it involves the name of the king and religious issues. Here as kings and rulers who had extensive knowledge, K.P.A Sontakusuma developed an exaggerated discourse in describing the king's power. Everything that comes out of the mouth of a king is a revelation of absolute truth that must be accepted. As for someone who spoke other than the king, the truth had to be questioned first, as in the quote below:

Èmpêre kaya wis katurunan wahyu Allah. Dene sakabèhe agama kaya wis dibuka ana ati, kok wong clathu sok nganèh-nganèhi mangka durung ana adate wong kêtiban wahyu jlêg sêka dhuwur sing tanpa jalaran.

[2586 / explanation of the 44th song]

Translate:

As it has received revelation from Allah. As for all religions, it has been opened in the heart, when someone speaks strangely even though it is not clear that people receive revelations that immediately fall from them without cause. [2586 / explanation of the 44th song]

K.P.A Sontakusuma's power of knowledge in conveying Yudanegara's teachings has always confirmed what the king said. He obtained education about culture and religion as a subjectivity in forming a subjective truth that was used as a discourse. In line with what Foucault said, a significant power-knowledge-truth relationship is practiced through language in the form of discourse. In discourse, truth will be constructed and form a power by itself [13].

The power in the literary work of Serat Sruti Jarwa by K.P.A Sontakusuma finally makes a separate truth which is addressed to his subordinates. K.P.A Sontokusuma tried to strengthen the position of the king as ruler and also his subordinate aristocrats to be respected by the people. The truth that was formed by the prince was only subjective truth, but in practice lived as a single truth by the society at that time because of the power of knowledge. This imposition of knowledge becomes an ideology that makes the people submit to the authorities.

\subsection{The Relevance of Yudanegara's Teachings in The Present}

The Yudanegara teaching in the Sruti Jarwa manuscript is a discourse from the ruler to maintain his power. Discourse becomes knowledge for the people to determine compliance with the state which is unconsciously the desire of the ruler. The values that can be obtained from Yudanegara's teachings are (1) good manners, (2) obedience to the leadership, (3) accepting fate, (4) patience, (5) resignation, (6) respect.

These values were used absolutely during the reign of King Pakubuwono IX in order to eliminate resistance and uphold the aristocratic class. Until now, the implication of this teaching is still visible in the form of a royal title (kaum ningrat) which is considered superior in Javanese society. The relevance of these values is considered to be still well used today. However, it is felt that the deification attitude of a leader cannot be used absolutely. 


\section{Conclusion}

The manuscript Serat Sruti Jarwa is a canonical literary work originating from the Surakarta Hadiningrat Palace written by K.P.A Sontakusuma around the year 1864 AD. In this literary work, there are Yudanegara teachings which contain teachings about the teachings of obedience. Yudanegara's teachings contain a discourse to legitimize the king's power because in it there is a cult of king's values as a single truth. this teaching strengthens the position of the king as ruler and also the aristocratic subordinates to be respected by the people.

The truth that is formed is only subjective truth, but in practice it is lived as a single truth by the people at that time because of the power of knowledge. This imposition of knowledge becomes an ideology that makes the people submit to the authorities. The values that can be obtained from Yudanegara's teachings are (1) good manners, (2) obedience to the leadership, (3) accepting fate, (4) patient, (5) resignation, (6) respect. This value can still be used today.

\section{References}

[1] Darusuprapta., Naskah-naskah Nusantara Beberapa Gagasan Penanganannya, Yogyakarta: Javanologi, 1984.

[2] B. Marsiwi, Alih Aksara Serat Sruti Jarwa (Srutjar) Karya K.P.A Sontakusuma, Jakarta: Perpusnas Press, 2019, p. 2.

[3] J. J. Yasraf Amar Piliang, Teori Budaya Kontemporer: Penjelajahan Tanda \& Makna, Yogyakarta: Aurora, 2018, p. 151.

[4] C. Barker, Cultural Studies : Teori dan Praktik, Yogyakarta: Kreasi Wacana, 2005, p. 109.

[5] M. Foucault, Power/Kowledge, New York: Pantheon, 1980, p. 136.

[6] J. J. Yasraf Amir Piliang, Teori Budaya Kontemporer: Penjelajahan Tanda \& Makna, Yogyakarta: Aurora, 2018, pp. 150-151.

[7] Cavallaro, Critical dan Cultural Theory, London: The Athlone Press, 2001, p. 21.

[8] N. K. Florida, Javanese Language Manuscrips of Surakarta Central Java A Pleriminary Descriptive Catalogus Level I and II, Michigan: Cornell University, 1993, p. 198.

[9] N. K. Florida, Jawa-Islam di Masa Kolonial, Yogyakarta: Buku Langgar, 2020, pp. 21-43.

[10] S. Kartodirjo, Perkembangan Peradaban Priyayi, Yogyakarta: UGM Press, 1987, pp. 27-32.

[11] D. Suratman, Kehidupan Dunia Keraton Surakarta 1830-1939, Yogyakarta: YUI, 2000, p. 209.

[12] A. Y. Lubis, Posmodernisme Teori dan Metode, Jakarta: Rajawali Pers, 2014, p. 80.

[13] A. Y. Lubis, Pemikiran Kritis Kontemporer, Jakarta: Rajawali Pers, 2015, p. 66. 